\title{
The evaluation and modification of a technique for comparing the efficiency of antiseptics against subcutaneously deposited bacteria in mice
}

\author{
LEONARD JEFFRIES AND S. A. PRICE \\ Walton Oaks Experimental Station, Dorking Road, Tadworth, Surrey
}

SYNOPSIS An attempt has been made to study the action of antiseptics on artificial streptococcalic 'wounds' in mice by a published technique (Martin, 1959). The results were not in agreement with $O$ those of Martin and the possible reasons for this are discussed. Suggestions are made for modi- $\stackrel{+}{\circ}$ fying the original method to increase its scope and precision. The production and treatment of ${ }_{-}^{\circ}$ $P$ s. pyocyanea and $\mathrm{Kl}$. aerogenes 'wounds' in mice is described and discussed.

Martin (1959) described a method for studying the action of antiseptics on subcutaneously deposited streptococci in mice. In the basic technique mice were anaesthetized with Avertin and a dose of Strep. pyogenes, sufficient to cause death in untreated mice, was injected subcutaneously; the needle was left in position and the antiseptic was injected through it into the same site 20 minutes later. Efficiency of the antiseptic was judged by comparison of mortality rates and mean survival times of treated mice which died with that of untreated controls. In some experiments attempts were made to simulate natural wound conditions by suspending both the streptococcus and antiseptic separately in horse blood. When antiseptics were dissolved in horse blood at the concentrations recommended by their respective manufacturers for the treatment of wounds chlorhexidine was stated by Martin to be markedly effective when compared with four quaternary ammonium compounds, the effects of which were judged to be slight. Of 14 'conventional antiseptics', presumably dissolved or suspended in water, eight were without effect, two were slightly effective, three were doubtful, and only one (acriflavine $0.1 \%$ ) was clearly active.

When we attempted to screen compounds synthesized in these laboratories by this method it became clear that there were complicating factors leading to death of mice such as anaesthetic and antiseptic toxicity. In our investigations we used a different strain of mouse and Streptococcus haemolyticus of a different Lancefield group from those used by Martin.

Received for publication 10 January 1964.

\section{EXPERIMENTAL MATERIALS}

ANAESTHETICS Two were tested.

Tribromethanol solution Avertin (Bayer Products Ltd., Kingston-on-Thames) was diluted 1 in 40 in $10 \%$ ethyl alcohol to give a $2.5 \%$ solution immediately before use, and tested with congo red to ensure that it had not decomposed.

Pentobarbitone sodium, B.P. solution Nembutal,

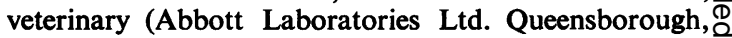
Kent), was diluted 1 in 10 in isotonic saline, to give $a \underset{\vec{F}}{\Rightarrow}$ $0.6 \%$ solution, which was freshly prepared before the $\frac{3}{3}$ start of each experiment.

MICE A closed colony of randomly-mated albino mice has been maintained for four years from stock supplied by Mr. F. Sullivan, Pharmacology Department, Guy's? Hospital Medical School. Mice within the weight range 3 of 17 to $20 \mathrm{~g}$. were used.

ANTISEPTICS Solutions or suspensions were prepared in $90 \%$ defibrinated horse blood or water by adding 1 윽 volume of aqueous antiseptic solution at 10 times the required strength to 9 volumes of blood or water. Ofo these, $0.2 \mathrm{ml}$. was administered subcutaneously in all experiments. The following antiseptics were tested:Chlorhexidine, phenoctide, domiphen bromide, benz- $N$ alkonium chloride, dequalinium chloride, and compound $\mathrm{N}$ 1162 (synthesized by, and under experimental investi- $\omega$ gation in, these laboratories).

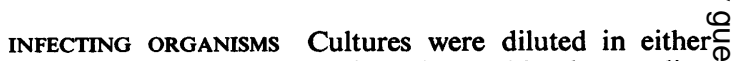
nutrient broth or $90 \%$ defibrinated horse blood, according to the experiment, and injected subcutaneously in $a_{T}$ volume of $0.05 \mathrm{ml}$.

Streptococcus haemolyticus, group C(Pion strain, C.N.4. Wellcome Collection of Bacteria). This strain was main- $\frac{\mathcal{Q}}{1}$ tained by regular passage through mice at weekly intervals. $\stackrel{D}{\Omega}$ 
Heart blood from a moribund infected mouse was inoculated into brain-heart infusion broth (Difco) containing $10 \%$ defibrinated horse blood and incubated overnight. On the following day $1 \mathrm{ml}$. was added to $10 \mathrm{ml}$. brain-heart infusion broth containing $10 \%$ normal horse serum, and incubated for six hours. For use the culture was diluted 1 in 1,000; this produced a fatal septicaemia in mice in 2 to $2 \cdot 5$ days.

Klebsiella aerogenes (N.C.T.C. 5055) This organism was deposited in the National Collection of Type Cultures in 1937 as Klebsiella pneumoniae. In accordance with the classification proposed by Cowan, Steel, Shaw, and Duguid (1960) it is now regarded as a strain of Klebsiella aerogenes (Steel, 1963). An overnight brainheart infusion broth culture diluted 1 in 1,000 regularly caused a septicaemia in mice and was fatal in an average time of 3.5 days. The virulence of this strain remained constant over seven months without 'mouse passage'.

Pseudomonas pyocyanea Two laboratory stock strains, one of which, W.O. 83, was originally isolated from a human wound infection, and W.O. 126 isolated from a case of bovine mastitis, were chosen.

A six-hour brain-heart infusion broth culture of either strain diluted 1 in 10 in horse blood produced a severe abscess at the injection site within six days in the majority of mice and a few mice died from septicaemia before the sixth day. The injection of fewer organisms resulted in lesions in only a small proportion of mice. Two other strains of $P s$. pyocyanea were found to be unsuitable as their virulence for mice, by the subcutaneous route, was too low.

THE TECHNIQUE OF SUBCUTANEOUS INJECTION AND TREATMENT WITH ANTISEPTICS

During the periods of induction of anaesthesia and recovery mice were placed on several layers of cellulose wadding in Harwell-pattern cages; shallow trays, similarly lined, were used in the actual experiments. Groups of mice were anaesthetized by the intraperitoneal injection of either Avertin of Nembutal. When all mice in a group were completely relaxed each animal was placed on its right side and rested against the inner edge of the tray.

Each mouse was injected subcutaneously in the region of the left shoulder with $0.05 \mathrm{ml}$. of bacterial suspension through a gauge 25 hypodermic needle attached to a tuberculin syringe. With care to avoid altering the position of its point in the subcutaneous tissues the needle was detached from the syringe and the hub was rested on the body of the mouse. Twenty minutes later $0.2 \mathrm{ml}$. of antiseptic solution was injected through the same needle, which was then removed. In the earlier experiments one group of control mice was used; these were infected and subsequently treated with $90 \%$ horse blood or saline. Later experiments included an additional group of mice which were also injected with $90 \%$ horse blood as a control of anaesthetic toxicity.

\section{EXPERIMENTS AND RESULTS}

EXPERIENCES WITH THE TECHNIQUE AS DESCRIBED BY MARTIN In Avertin-anaesthetized mice infected with Strep. haemolyticus and treated with $0.1 \%$ chlorhexidine, $0.1 \%$ compound 1162 , or $0.5 \%$ phenoctide the mortality rates were high in all groups whether or not $90 \%$ horse blood was used for suspending the antiseptics and bacteria. All mice in the saline-treated infection control groups died and so also did those treated with $0.5 \%$ phenoctide. The phenoctide-treated mice in fact died earlier than the saline-treated controls, but whereas Strep. haemolyticus was recovered from the heart blood of all the control mice it could not be recovered from most of the mice that had been treated with phenoctide. It was apparent therefore that the deaths may have been due to the toxicity of this antiseptic which nevertheless killed the streptococcus at the injection site. Subsequent experiments with unanaesthetized mice have confirmed that $0.5 \%$ phenoctide is indeed toxic and that anaesthetized mice are killed by even lower concentrations.

Scrutiny of Martin's results reveals that he too found the survival times of infected mice treated with $0.5 \%$ phenoctide to be shorter than those of infected controls. He assumed that deaths were due to infection and concluded that the activity of phenoctide, at the recommended level of $0.5 \%$, was very slight. We consider that the antiseptic is toxic at that level and that it is necessary to test at lower levels in order to demonstrate its antibacterial activity uncomplicated by toxicity.

We found that Avertin solution, diluted as recommended by Martin and injected intraperitoneally in a dose of $0.2 \mathrm{ml}$., was toxic to approximately $30 \%$ of our mice within the weight range 17-22 g. Ten per cent of mice died within six hours of injection and a further $20 \%$ regained consciousness but subsequently died during the following five days.

From Martin's original description and discussion this ingenious technique appeared to represent a potential advance on previously described methods. We found, however, that toxicity, both of anaesthetic and antiseptic, may be serious complicating factors that may readily vitiate results.

\section{MODIFICATIONS TO THE BASIC TECHNIQUE}

CHOICE OF ANAESTHETIC In his description of Avertin anaesthesia Martin stated: 'This anaesthetic was found superior to pentobarbitone for this purpose, because deaths from the anaesthetic did not occur'.

Some strains of mice are known to be more sensitive to Avertin than to Nembutal (pentobarbitone) and vice versa and, for this reason, different workers favour one or other anaesthetic (Brown, 1963). It is possible that some of the deaths 
in the experiments reported by Martin may also have been due to delayed toxicity of Avertin.

Nembutal solution diluted 1 in 10 in saline was given intraperitoneally in doses from $0.15 \mathrm{ml}$. to $0.3 \mathrm{ml}$. to groups of mice of both sexes in the weight range $17-20 \mathrm{~g}$. No sexual differences in reaction to the anaesthetic were noted. With doses of less than $0.25 \mathrm{ml}$. the depth of anaesthesia, as judged by degree of relaxation and reaction to a needle prick of the skin, was unsatisfactory. A dose of $0.3 \mathrm{ml}$. was toxic to $30 \%$ of mice within six hours of dosing; mice surviving this time were still alive at the end of the nine-day observation period.

From these preliminary experiments a dose of $0.25 \mathrm{ml}$. Nembutal (approximately $75 \mathrm{mg} . / \mathrm{kg}$.) appeared to be satisfactory and this dose was used to anaesthetize 1,000 mice used in subsequent infection and toxicity experiments. In most experiments a group of anaesthetic control mice was used. These were anaesthetized and $\mathbf{3 0}$ minutes later were injected with $0.2 \mathrm{ml}$. of $90 \%$ horse blood in saline. Altogether 90 mice were used for this purpose; $3.4 \%$ of these died within six hours of anaesthesia and the remainder survived the duration of the experiment.

It is essential to test anaesthetic toxicity on the strain of mouse to be used in this technique; the mice should be observed for nine days. It is also recommended that an anaesthetic control group of mice should be included in each experiment involving anaesthesia.

ANTISEPTIC TOXICITY TESTS IN MICE ANAESTHETIZED WITH NEMBUTAL Mice in groups of seven to 10 were anaesthetized with Nembutal and 30 minutes later they were injected subcutaneously with $0.2 \mathrm{ml}$. of antiseptic solution or suspension in $90 \%$ horse blood. As a result of these experiments it was established that the antiseptics to be studied could all be safely administered to Nembutal-anaesthetized. mice at the following concentrations (the con $\overrightarrow{\bar{c}}$ centrations recommended for wound treatment are shown in brackets):- Chlorhexidine diacetate

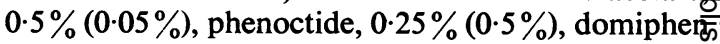
bromide, $0.5 \%(0.5 \%)$, benzalkonium chloride $0.1 \%(0.1 \%)$, dequalinium chloride, $0.4 \%(0.4 \%$ in 'tulle gras'), and compound $1162,0.5 \%$.

RECOVERY OF INFECTING ORGANISM FROM MICE A infected mice dying during the course of experic ments were examined after death and heart-bloof cultures were made on blood agar. Further cultures? as described below, were prepared from surviving $\vec{v}$ mice infected with Ps. pyocyanea.

APPLICATION OF THE MODIFIED TECHNIQUE TO TH EVALUATION OF ANTISEPTICS AGAINST THREE DIFFERENT INFECTING ORGANISMS

STREPTOCOCCUS HAEMOLYTICUS In the experiment

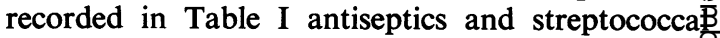
suspension were prepared in $90 \%$ horse blood. The antiseptics were administered 20 minutes after infection and mice were observed for nine dayse Septicaemia was confirmed as the cause of death by recovery of the streptococcus from the hearb blood of all mice that died. The number of mice in each group varied from one experiment to anothe due to supply. Variation in the number of mice i⿱亠凶禸 the groups within an experiment was due to anaes thetic deaths and technical failures, such as blockag $\vec{s}$ or misplacement of the hypodermic needle.

Table I, experiment 1 , shows that chlorhexidine and domiphen bromide were active at the recom? mended user concentration and dequaliniuns chloride was active at the concentration in which it is used in a mixture (Wilkinson, 1959). Compound 1162 was active at an arbitrarily selected concentrac

TABLE I

THE EFFECT OF ANTISEPTICS USING STREP. HAEMOLYTICUS AS TEST ORGANISM

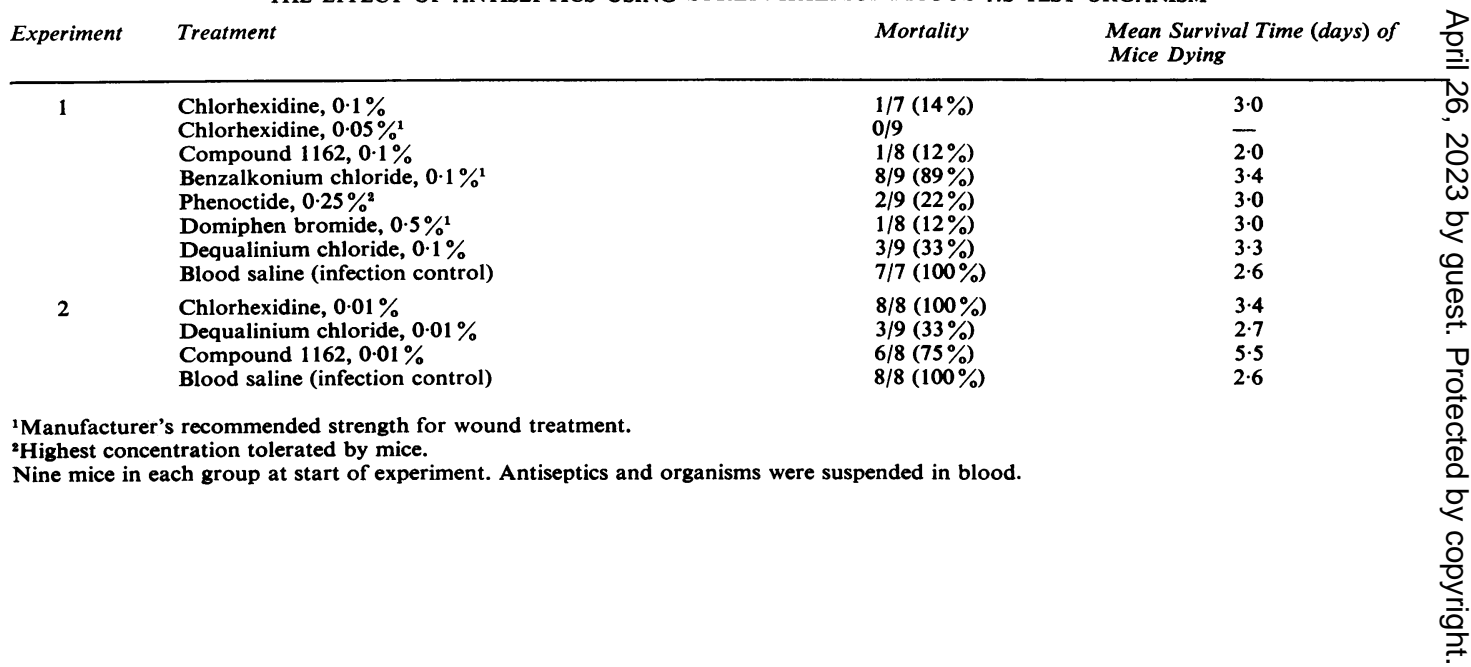


TABLE II

EFFECT OF ANTISEPTICS USING STREP. HAEMOL YTICUS AS TEST ORGANISM ${ }^{1}$

\begin{tabular}{|c|c|c|c|}
\hline Experiment & Treatment & Mortality & $\begin{array}{l}\text { Mean Survival Time (days) of } \\
\text { Mice Dying }\end{array}$ \\
\hline 1 & $\begin{array}{l}\text { Domiphen bromide, } 0.5 \% \\
\text { Domiphen bromide, } 0.1 \% \\
\text { Phenoctide, } 0.1 \% \\
\text { Blood saline (infection control) }\end{array}$ & $\begin{array}{l}1 / 8(12 \%) \\
1 / 8(12 \%) \\
1 / 8(12 \%) \\
8 / 8(100 \%)\end{array}$ & $\begin{array}{l}1 \cdot 0 \\
4 \cdot 0 \\
3 \cdot 0 \\
2 \cdot 5\end{array}$ \\
\hline 2 & $\begin{array}{l}\text { Chlorhexidine, } 0.1 \% \\
\text { Chlorhexidine, } 0.01 \% \\
\text { Phenoctide, } 0.01 \% \\
\text { Domiphen bromide, } 0.01 \%\end{array}$ & $\begin{array}{l}1 / 10(10 \%) \\
10 / 10(100 \%) \\
10 / 10(100 \%) \\
10 / 10(100 \%)\end{array}$ & $\begin{array}{l}1 \cdot 0 \\
2 \cdot 8 \\
2 \cdot 8 \\
2 \cdot 3\end{array}$ \\
\hline 3 & $\begin{array}{l}\text { Benzalkonium chloride, } 0.1 \% \\
\text { Compound } 1162,0.1 \% \\
\text { Compound } 1162,0.01 \% \\
\text { Blood saline (infection control) }\end{array}$ & $\begin{array}{l}4 / 9(44 \%) \\
0 / 9 \\
9 / 9(100 \%) \\
10 / 10(100 \%)\end{array}$ & $\begin{array}{l}3 \cdot 25 \\
-3 \cdot 66 \\
2 \cdot 2\end{array}$ \\
\hline
\end{tabular}

${ }^{1}$ Antiseptics were dissolved in blood, and streptococcus was suspended in broth.

TABLE III

INFLUENCE OF BLOOD AND BROTH AS SUSPENDING AGENTS FOR THE STREPTOCOCCUS ON THE ACTIVITY OF CERTAIN ANTISEPTICS DISSOLVED IN BLOOD

\begin{tabular}{|c|c|c|c|}
\hline Treatment & $\begin{array}{l}\text { Medium for Suspension of } \\
\text { Streptococcus }\end{array}$ & Mortality & $\begin{array}{l}\text { Mean Survival Time (days) of } \\
\text { Mice Dying }\end{array}$ \\
\hline $\begin{array}{l}\text { Phenoctide, } 0.1 \% \\
\text { Phenoctide, } 0.1 \% \\
\text { Domiphen bromide, } 0.1 \% \\
\text { Domiphen bromide, } 0.1 \% \\
\text { Blood saline (infection control) }\end{array}$ & $\begin{array}{l}\text { Blood } \\
\text { Broth } \\
\text { Blood } \\
\text { Broth } \\
\text { Blood }\end{array}$ & $\begin{array}{c}9 / 10(90 \%) \\
3 / 10(30 \%) \\
7 / 10(70 \%) \\
1 / 10(10 \%) \\
10 / 10(100 \%)\end{array}$ & $\begin{array}{l}2 \cdot 8 \\
2 \cdot 3 \\
2 \cdot 3 \\
2 \cdot 0 \\
2 \cdot 2\end{array}$ \\
\hline
\end{tabular}

tion and benzalkonium chloride showed only slight activity. Phenoctide was active at the maximum tolerated concentration.

In Table I, experiment 2, three of the compounds shown to be active in experiment 1 were diluted further (five to ten fold) and, judging from mortality rates and mean survival times, compound 1162 and dequalinium chloride appeared to be more active than chlorhexidine.

Whether or not it would be possible to distinguish between the activities of compound 1162 and dequalinium chloride by further tests against the streptococcus has not been investigated.

It was found that, when the streptococcus was suspended in broth instead of $90 \%$ horse blood, the needle became blocked less frequently. Martin found that the mean survival time of infected, untreated mice was the same whether blood or broth was used for suspending the streptococcus; we have confirmed this. The results in Tables I and II, together with those of other experiments for which there is not space to detail, suggested that certain antiseptics were adversely affected by the use of blood instead of broth for suspending the streptococcus. Table III, in which two quaternary ammonium compounds were compared at one fifth the recommended user levels in one experiment, illustrates this effect.

When chlorhexidine, phenoctide, domiphen bromide, benzalkonium chloride, and compound 1162 solutions at $0.1 \%$ in blood were tested against the streptococcus suspended in broth all five were active. When the same concentrations of antiseptics in blood were tested against the streptococcus suspended in blood the activities of phenoctide, domiphen bromide, and benzalkonium chloride were reduced. It would therefore appear that streptococci suspended in blood are less accessible to certain antiseptics although these antiseptics are also suspended in blood; it is not clear to us why this should be.

Martin's conclusion that, at the recommended user levels, chlorhexidine was more effective than phenoctide and domiphen bromide may be erroneous, as he failed to exclude anaesthetic and antiseptic toxicity, nor did he state that he had established infection as the cause of deaths.

By the modified technique, in which all deaths were confirmed as streptococcal, we found domiphen bromide to be active at the recommended user level. Phenoctide was active at a lower level than that tested by Martin.

PSEUdOMONAS PYOCYANEA Ps. pyocyanea appears to be of low virulence for mice by the subcutaneous route. We found that the subcutaneous injection of large numbers of cells of the more virulent strains caused septicaemia fatal within six days in only a 
small proportion of mice; the remainder developed local abscesses. Two such strains were selected for this investigation.

Groups of mice were anaesthetized with Nembutal and injected subcutaneously with $0.05 \mathrm{ml}$. of a six-hour Ps. pyocyanea culture diluted 1 in 10 in either broth or $90 \%$ horse blood. The antiseptic solution in horse blood was injected into the same site 20 minutes later. Cultures were prepared from the heart blood of any mice that died during the following six days; survivors were then killed and the tissues at the site of injection were dissected. Lesions were recorded and any contents were examined by Gram's stain and inoculated on to agar plates, which were incubated for three days. Most antiseptics, in the concentrations tested, produced slight tissue necrosis. Infected lesions, however, were usually easily distinguished and confirmed by demonstration of pus cells and Gramnegative bacilli microscopically and the growth of $P$ s. pyocyanea in culture. In untreated mice abscesses started to resolve after the sixth day.

Although results were similar whether horse blood or broth was used for suspending the Ps. pyocyanea, blood was used in most experiments. The results of three such experiments, using Ps. pyocyanea (strain W.O. 83), are given in Table IV.

It will be seen from Table IV that benzalkonium chloride, domiphen bromide, and dequalinium chloride, in the concentrations recommended for wound treatment and shown to be non-toxic to mice, and phenoctide, at the highest level tolerated by mice, did not suppress $P$ s. pyocyanea infection. Chlorhexidine, at the user level of $0.05 \%$, showed considerable protection and at $0.1 \%$ the effect was marked.
It is of interest to note that, although all infected, untreated control mice showed local abscesses due tow Ps. pyocyanea when they were killed, only one out of ao total of 28 such mice (Table IV) died from septic-0 aemia. In contrast, a high proportion of mices treated with ineffective quaternary ammoniump compounds died from septicaemia. Phenoctide and domiphen bromide, although clearly ineffective at? high concentrations, were tested at a single lower level and the proportion of mice dying from $\overrightarrow{-}$ septicaemia was not reduced; still lower doses were not tried. These observations are presumably relateक to the mechanism of drug toxicity on the infected mouse, and certain observations of Dutton (1955) may be relevant.

Dutton (1955), in a study of the effect of the route of injection on lethal infection of mice, found that eight species of bacteria were less lethal when injected intravenously than by either the intraes peritoneal or subcutaneous routes. He suggeste $B$ that the more rapidly certain bacteria reach the blood stream (via macrophages and lymphatics) from a primary site the greater is the possibility of the host's survival. Thus localization of the infectingo organism at the primary site is not necessarily the most effective defence reaction. It may be that certain antiseptics, such as phenoctide, interfere with the mechanism for the removal of small numbers of Ps. pyocyanea from the subcutaneous site to the blood stream where they could be destroyed, an thereby permit the development of a focus of infection of severe degree that ultimately overō whelms the host and produces a fatal septicaemia? It may be possible to develop a method, based on this phenomenon, for studying the toxicity of antiseptics to wound tissue. It is well known that the

TABLE IV

EFFECT OF ANTISEPTICS DISSOLVED IN BLOOD AGAINST PS. PYOCYANEA

\begin{tabular}{llll} 
Experiment & \multicolumn{3}{c}{ (STRAIN W.O. 83) INFECTION } \\
No. of Mice in $\begin{array}{l}\text { Mortality from Ps. } \\
\text { pyocyanea Septicaemia }\end{array}$ & $\begin{array}{l}\text { No. of Survivors with } \\
\text { Lesions due to Ps. } \\
\text { pyocyanea }\end{array}$
\end{tabular}

\begin{tabular}{|c|c|c|c|c|c|c|}
\hline \multirow[b]{2}{*}{1} & \multirow[b]{2}{*}{$\begin{array}{l}\text { Chlorhexidine, } 0.1 \% \\
\text { Chlorhexidine, } 0.05 \% \\
\text { Blood saline (infection control) }\end{array}$} & \multirow[b]{2}{*}{$\begin{array}{r}10 \\
9 \\
11\end{array}$} & \multirow{2}{*}{$\begin{array}{c}\text { No. of Mice } \\
0 \\
0 \\
1\end{array}$} & \multirow{2}{*}{$\frac{\% \text { of Total }}{-}$} & \multirow[b]{2}{*}{$\begin{array}{r}1 \\
5 \\
10\end{array}$} & \multirow[b]{2}{*}{$\begin{array}{r}10 \\
55 \\
100\end{array}$} \\
\hline & & & & & & \\
\hline 2 & $\begin{array}{l}\text { Chlorhexidine, } 0 \cdot 1 \% \\
\text { Phenoctide, } 0 \cdot 25 \% \\
\text { Domiphen bromide, } 0.5 \% 1 \\
\text { Benzalkonium chloride, } 0 \cdot 1 \% 1 \\
\text { Blood saline (infection control) } \\
\text { Chlorhexidine, } 0 \cdot 1 \%\end{array}$ & $\begin{array}{r}9 \\
10 \\
9 \\
10 \\
9 \\
8\end{array}$ & $\begin{array}{r}0 \\
10 \\
4 \\
7 \\
0 \\
0\end{array}$ & $\begin{array}{l}\overline{100} \\
44 \\
70 \\
- \\
-\end{array}$ & $\begin{array}{l}0 \\
5 \\
2 \\
9 \\
1\end{array}$ & $\begin{array}{r}0 \\
100 \\
100 \\
90 \\
100 \\
12\end{array}$ \\
\hline 3 & $\begin{array}{l}\text { Compound } 1162,0.1 \% \\
\text { Dequalinium chloride, } 0.4 \% \\
\text { Phenoctide, } 0.1 \% \\
\text { Domiphen bromide, } 0.1 \% \\
\text { Blood saline (infection control) }\end{array}$ & $\begin{array}{l}7 \\
9 \\
9 \\
8 \\
8\end{array}$ & $\begin{array}{l}1 \\
5 \\
9 \\
5 \\
1\end{array}$ & $\begin{array}{r}14 \\
55 \\
100 \\
62 \\
12\end{array}$ & $\begin{array}{r}6 \\
-3 \\
7\end{array}$ & $\begin{array}{l}100 \\
100 \\
100 \\
100 \\
100\end{array}$ \\
\hline \multicolumn{7}{|c|}{${ }^{1}$ Manufacturer's recommended strength for wound treatment. } \\
\hline
\end{tabular}


TABLE V

\begin{tabular}{|c|c|c|c|c|c|}
\hline \multirow{3}{*}{ Experiment } & \multicolumn{5}{|c|}{ EFFECT OF ANTISEPTICS AGAINST $K L$. AEROGENES INFECTION } \\
\hline & \multirow[t]{2}{*}{ Treatment } & No. of Mice in Group & \multicolumn{2}{|c|}{$\begin{array}{l}\text { Mortality from Kl. aerogenes } \\
\text { Septicaemia }\end{array}$} & \multirow[t]{2}{*}{$\begin{array}{l}\text { Mean Surviva } \\
\text { of Mice Dying }\end{array}$} \\
\hline & & & No. of Mice & $\%$ of Total & \\
\hline 1 & $\begin{array}{l}\text { Chlorhexidine, } 0.1 \% \\
\text { Chlorhexidine, } 0.05 \% \\
\text { Domiphen bromide, } 0.5 \% 1 \\
\text { Blood saline (infection control) }\end{array}$ & $\begin{array}{r}10 \\
9 \\
10 \\
11\end{array}$ & $\begin{array}{r}1 \\
2 \\
4 \\
11\end{array}$ & $\begin{array}{r}10 \\
22 \\
40 \\
100\end{array}$ & $\begin{array}{l}5 \cdot 0 \\
4 \cdot 5 \\
5 \cdot 0 \\
3 \cdot 8\end{array}$ \\
\hline 2 & $\begin{array}{l}\text { Chlorhexidine, } 0 \cdot 1 \% \\
\text { Compound } 1162,0 \cdot 1 \% \\
\text { Domiphen bromide, } 0 \cdot 5 \%^{1} \\
\text { Phenoctide, } 0.25 \% \\
\text { Benzalkonium chloride, } 0.1 \%{ }^{1} \\
\text { Blood saline (infection control) }\end{array}$ & $\begin{array}{r}11 \\
11 \\
9 \\
11 \\
10 \\
10\end{array}$ & $\begin{array}{r}0 \\
11 \\
5 \\
11 \\
10 \\
10\end{array}$ & $\begin{array}{r}- \\
100 \\
55 \\
100 \\
100 \\
100\end{array}$ & $\begin{array}{l}3 \cdot 63 \\
4 \cdot 0 \\
2 \cdot 54 \\
3 \cdot 9 \\
3 \cdot 3\end{array}$ \\
\hline
\end{tabular}

${ }^{1}$ Manufacturer's recommended strength for wound treatment.

All mice were observed for nine days.

results of studies in vitro on leucocyte damage by antiseptics may be considerably influenced by the techniques used and their relevance and reproducibility have been questioned (Fleming, 1940; Garrod, 1955).

With infection produced by another strain of Ps. pyocyanea (W.O. 126) seven out of 10 mice treated with $0.1 \%$ chlorhexidine in blood and all 10 bloodsaline treated mice showed abscesses on the sixth day.

KLEBSIELLA AEROGENES Nembutal-anaesthetized mice were injected subcutaneously with $0.05 \mathrm{ml}$. of an overnight broth culture of $\mathrm{Kl}$. aerogenes diluted 1 in 1,000 in $90 \%$ horse blood; antiseptics, suspended in blood, were injected 20 minutes later. The results of two separate experiments are shown in Table V.

This organism was tested because it is a highly mouse-pathogenic encapsulated strain and representative of a group of coliforms that are potential pathogens of man. At the recommended user level, against this Klebsiella strain, domiphen bromide showed a moderate degree of activity and chlorhexidine showed a more marked effect. Phenoctide, at the maximum level that could be tested, and benzalkonium chloride, at user level, were without effect.

\section{DISCUSSION}

The difficulties inherent in the laboratory testing of antiseptics are well known and have been extensively reviewed by, for example, Garrod (1955) and Sykes (1958). The comparison, one with another, of substances of widely different chemical structure having diverse modes of antibacterial action and a wide variety of toxic effects on the host inevitably poses complex problems. Indeed, any attempt to compare, by tests on living systems, qualitatively different substances is at variance with the established principles of biological assay. The evaluation of an antiseptic must depend, therefore, on the application of carefully selected tests and a critical appraisal of the results obtained rather than on a comparison of one compound against another by any single laboratory procedure; on the basis of such evaluation the compounds most meriting clinical trial must be chosen.

Although there is an extensive literature on the testing in vitro of wound antiseptics relatively few methods have been described for testing in animals. Attempts have been made to assess antiseptic activity in mice by intraperitoneal injection immediaately before, or at various intervals after, infection with lethal inocula of bacteria by the same route (Babbs, Collier, Austin, Potter, and Taylor, 1956; Cox and D'Arcy, 1963; Davies, Francis, Martin, Rose, and Swain, 1954). Such procedures might be criticized on the grounds that peristalsis may rapidly disperse intraperitoneally injected organisms creating multiple foci of infection that may be inaccessible to the antiseptic.

Methods involving the establishment of experimental wounds have been discussed by Martin (1959). Such methods, as he points out, have failed to control all the variables influencing the result and the indwelling needle technique should go far towards meeting this difficulty. The technique was able to differentiate between compounds of marked inhibitory action in vitro although no great precision could be claimed for it. Our results have confirmed that the test, with certain modifications, is of value for this purpose.

The choice of concentration of antiseptic to be tested presents some difficulty. In general, we would recommend that the highest non-toxic concentration should be used but it is imperative that the non-toxic level should be established with some care-itself a difficult procedure that may be influenced by the choice of anaesthetic. If, under 
these conditions, antiseptic A proves 'better' than antiseptic $B$ then could higher doses of $B$ be tolerated and the rating reversed? Alternatively, if $A$ is 'effective' at a markedly lower level than B is it necessarily a 'better' antiseptic? Calman and Murray (1956), in a study of antiseptics for use in obstetrics, pointed out the importance of the economic aspect in their practical evaluation. Effectiveness at low concentrations may tempt the manufacturers of an expensive compound to recommend the lowest concentration consistent with efficiency, but the principal advantage of better antiseptics should be that they can safely be used at more effective levels.

In the technique as originally developed by Martin Streptococcus pyogenes was the only organism used for infection of the mice. We regard the extension of the technique to include other test organisms as a valuable modification. The number of bacterial species, however, that will produce either local or systemic infection in mice is small. In view of the importance of Staph. aureus in hospital infections at the present time, this would be a most realistic test organism. Unfortunately, administered by the subcutaneous route to mice, it is well tolerated (Smith, Wilson, Hazard, Hummer, and Dewey, 1960) and we were unable, with any of six strains of Staph. aureus, to produce systemic infections after subcutaneous injection of broth cultures. We have, however, been able to produce local abscesses by subcutaneous injection of suitable strains, the severity and frequency of which could be enhanced by gastric mucin. Such abscesses were readily prevented by antiseptics. Further work is in progress to determine whether the influence of antiseptics on staphylococcal abscess formation could be used as the basis of a method for antiseptic differentiation. Recent reports suggest that $P$ s. pyocyanea infections are increasing in frequency and severity and, for these reasons, Ps. pyocyanea would appear to be an important organism to include in antiseptic screening tests in mice.

Extension of the technique to include other microorganisms has emphasized the importance not only of species but also of strain differences in attempts to rank antiseptics for efficiency. Thus, our two strains of Ps. pyocyanea, both of which were equally sensitive to chlorhexidine in vitro differ markedly in their susceptibility to the anties bacterial action of chlorhexidine when tested by the indwelling needle technique. It would be interesting? to know what proportion of Psuedomonas pyocyane strains isolated from wound infections would prove virulent for mice and show sensitivity to chlore hexidine by this method. Furthermore, compound 1162 , which proved highly effective against th streptococcus and superior to chlorhexidine when tested at the very low level of $0.01 \%$, was ineffective when Pseudomonas pyocyanea was used as the teso organism.

When applied critically with due regard for the spurious effects that may be unwittingly introduced through anaesthetic or antiseptic toxicity, an $\$$ considered in conjunction with results of sensitivity tests in vitro and contact time estimations, we are of the opinion that this technique can provide valuables information on the relative merits of antiseptics an on their suitability for clinical trials.

We thank Mr. W. A. Freeman, May \& Baker Ltd., fo the strain of $\mathrm{Kl}$. aerogenes and Mr. C. D. Wilson, Centrat Veterinary laboratories, Weybridge, for one strain of Ps. pyocyanea. For advice on the anaesthesia of mice wet are grateful to Dr. Annie Brown, Laboratory Animalo Centre, Carshalton, and for information concerning the identity of the $\mathrm{Kl}$. aerogenes strain we thank Dr. K. J Steel, National Collection of Type Cultures. We are also indebted to the manufacturers of some of the antiseptics for providing us with samples of their products fo? investigation.

\section{REFERENCES}

Babbs, M., Collier, H. O. J., Austin, w. C., Potter, M. D., and Taylor, E. P. (1956). J. Pharm. Pharmacol., 8, 110. Brown, Annie (1963). Personal communication.

Calman, R. M., and Murray, J. (1956). Brit. med. J., 2, 200.

Cowan, S. T., Steel, K. J., Shaw, C., and Duguid, J. P. (1960). J. gen. Microbiol., 23, 601.

Cox, W. A., and D'Arcy, P. F. (1963). J. Pharm. Pharmacol., 15, 129 Davies, G. E., Francis, J., Martin, A. R., Rose, F. L., and Swain, GB (1954). Brit. J. Pharmacol., 9, 192.

Dutton, A. A. C. (1955). Brit. J. exp. Path., 35, 128.

Fleming, A. (1940). Proc. roy. Soc. Med., 36, 487.

Garrod, L. P. (1955). Ibid., 48, 21.

Martin, A. R. (1959). J. clin. Path., 12, 48.

Smith, I. M., Wilson, A. P., Hazard, E. C. Hummer, W. K., anâ Dewey, M. E. (1960). J. infect. Dis., 107, 369.

Steel, K. J. (1963). Personal communication.

Sykes, G. (1958). Disinfection and Sterilization. Spon, London. Wilkinson, D. S. (1959). Practitioner, 182, 501. 